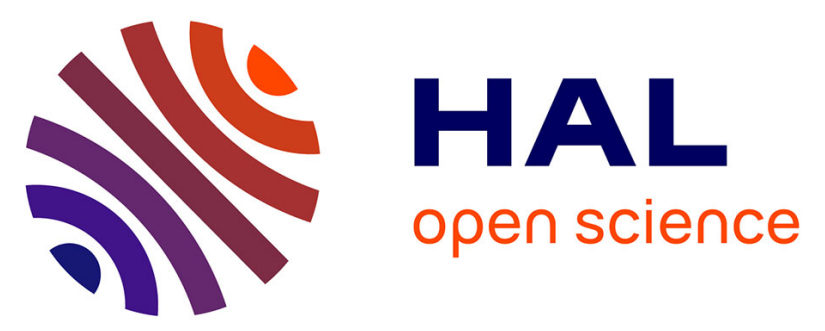

\title{
Iron and Cobalt Metallotropism in Remote-Substituted NHC Ligands: Metalation to Abnormal NHC Complexes or NHC Ring Opening
}

Andreas A Danopoulos, Alexandre Massard, Gilles Frison, Pierre Braunstein

\section{- To cite this version:}

Andreas A Danopoulos, Alexandre Massard, Gilles Frison, Pierre Braunstein. Iron and Cobalt Metallotropism in Remote-Substituted NHC Ligands: Metalation to Abnormal NHC Complexes or NHC Ring Opening. Angewandte Chemie International Edition, 2018, 57 (44), pp.14550-14554. 10.1002/anie.201808008 . hal-01927645

\section{HAL Id: hal-01927645 \\ https://hal.science/hal-01927645}

Submitted on 11 Jun 2019

HAL is a multi-disciplinary open access archive for the deposit and dissemination of scientific research documents, whether they are published or not. The documents may come from teaching and research institutions in France or abroad, or from public or private research centers.
L'archive ouverte pluridisciplinaire HAL, est destinée au dépôt et à la diffusion de documents scientifiques de niveau recherche, publiés ou non, émanant des établissements d'enseignement et de recherche français ou étrangers, des laboratoires publics ou privés. 


\title{
Iron and Cobalt Metallotropism in Remote-Substituted NHC Ligands, Metallation to Abnormal NHC Complexes or NHC Ring Opening
}

\author{
Andreas A. Danopoulos, ${ }^{*[a],[b]}$ Alexandre Massard, ${ }^{[a]}$ Gilles Frison, ${ }^{[c]}$ and Pierre Braunstein ${ }^{*[a]}$ \\ Dedicated to Prof. Richard J. Puddephatt on the occasion of his 75th birthday, with our warmest congratulations and best wishes.
}

\begin{abstract}
Metallotropism of the $\mathrm{M}\left[\mathrm{N}\left(\mathrm{SiMe}_{3}\right)_{2}\right]_{2}$ metal fragment in the tautomeric system $I A^{R} \rightleftharpoons A C^{R}$ involving imidazolium salts / Nheterocyclic carbenes with remote amine / aminide substituents, respectively, is manifested by its $\mathrm{C}_{\mathrm{NHC}}$ carbophilicity $(\mathrm{R}=t \mathrm{Bu}, \mathrm{M}=\mathrm{Co}$, $\mathrm{Fe})$ or $\mathrm{NR}_{\text {aminido }}$ nitrogenophilicity $(\mathrm{R}=\mathrm{Cy}, \mathrm{M}=\mathrm{Co}, \mathrm{Fe} ; \mathrm{R}=\mathrm{Mes}, \mathrm{M}=$ $\mathrm{Fe}$ ) and has been rationalized on the basis of steric and electronic effects. The thermolysis products of the $\left[\mathrm{M}\left\{\mathrm{N}\left(\mathrm{SiMe}_{3}\right)_{2}\right\}_{2}\right] / I \boldsymbol{A}^{R} \rightleftharpoons \boldsymbol{A} \boldsymbol{C}^{R}$ system are also substituent-dependent, leading to a rearranged aminide-functionalized $\mathrm{aNHC} \mathrm{Co} 2$ complex of an unprecedented type or to ring-opened metallaketenimines; they are postulated to originate from different metalloisomers. The results are interpreted on the basis of the X-ray diffraction analysis of 11 new compounds.
\end{abstract}

Molecular complexity in metal-centered chemistry heavily relies on ligands, and their own versatility is enhanced by their functionalization. If simple $\mathrm{N}$-heterocyclic carbene $(\mathrm{NHC})$ ligands have already led to impressive achievements in numerous areas of chemistry, functionalized $\mathrm{NHC}$ often bring about additional properties of considerable impact in structural chemistry, catalysis, material science, medicine, etc.. $\mathrm{N}$-heterocyclic 'remote'substituted imidazol-2-ylidenes $r(\mathrm{NHCs})$ with heteroatom substituents at the 4- and / or 5-positions of the heterocycle (denoted as $r$ (substituent)) have been studied apropos of modulating the nucleophilicity and donor properties of the NHC functionality by means of the inductive and mesomeric effects of the $r$ (substituent). Diverse substituent types have been described, resulting in $\mathrm{NHC}$ ligands that are charge-neutral, cationic or anionic (e.g. $r\left(\mathrm{~N}_{\text {exo }} \mathrm{R}_{2}\right), r\left(\mathrm{~N}_{\mathrm{exo}} \mathrm{HR}\right), r\left(\mathrm{PPh}_{2}\right), r(\mathrm{RS}), r\left(\mathrm{SiMe}_{3}\right)$, $r\left(\mathrm{SiPh}_{3}\right){ }^{[1]}$ or $r\left(\mathrm{PPh}_{3}{ }^{+}\right)$and $r\left(\mathrm{Nexo}_{\mathrm{ex}} \mathrm{H}_{3}{ }^{+}\right)^{[2]}$ or $r\left[\mathrm{~B}\left(\mathrm{Ar}_{3}\right)^{-}\right], r\left(\mathrm{O}^{-}\right)$and $r\left(\mathrm{~N}_{\text {exo }} \mathrm{R}^{-}\right)$, respectively)..$^{[1,19,3]}$ Neutral and anionic $r$ (substituents) can render the $r \mathrm{NHCs}$ ambident, occasionally acting as bridging ligands. ${ }^{[4]}$ Competition between the $\mathrm{C}_{\mathrm{NHC}}$ and $r$ (substituent) sites for metal coordination is sterically and electronically tunable. ${ }^{[3 a]}$

[a] Prof. Dr. A. A. Danopoulos, Dr. A. Massard, Prof. Dr. P. Braunstein Université de Strasbourg, CNRS, Chimie UMR 7177

Laboratoire de Chimie de Coordination

4 rue Blaise Pascal, 67081 Strasbourg Cedex (France)

E-mail : A.Danopoulos@chem.uoa.gr braunstein@unistra.fr

[b] Prof. Dr. A. A. Danopoulos

Chemistry Department

National and Kapodistrian University of Athens

Panepistimiopolis Zografou, 15771 Athens (Greece)

[c] Prof. Dr Gilles Frison

LCM, CNRS

Ecole polytechnique, Université Paris-Saclay,

91128 Palaiseau Cedex (France)

Supporting information for this article can be found under: https ://doi.org/10.1002/anie...
Tautomeric equilibria involving the $\mathrm{C}_{\mathrm{NHC}}$ basic site and the $r$ (substituent), altering the nature and electronic characteristics of the donors, can lead to increased bonding diversity (cf. equilibria involving Nitron, recently extended to its alkyl analogues ${ }^{[5]}$ and other mesomeric betaines ${ }^{[6]}$ ). With 1,3-bis-(DiPP)imidazolium systems (DiPP = diisopropylphenyl), the tautomerism between the Imidazolium Aminide (IA) (with anionic $r\left(N_{\text {exo }} R\right)$ ) and the Amino Carbene $(\boldsymbol{A C})$ (with neutral $r(\mathrm{NHR})$ ) depends on the nature of R: aromatic and tBu substituents favor the $\boldsymbol{I A}$ and $\boldsymbol{A C}$ forms, respectively (Scheme 1). ${ }^{[7]}$ When $\mathrm{R}=t \mathrm{Bu}$, both tautomers could be isolated from the equilibrium mixture $I A^{t B u} \rightleftharpoons A C^{t B u}$ and crystallographically characterized: the $I A^{t B u}[7]$ by cooling at $-40^{\circ} \mathrm{C}$ and the $\boldsymbol{A} \boldsymbol{C}^{\mathrm{tBu}}$ by slow solvent evaporation at room temp. (Supporting Information and Figure S2.1).<smiles>[R]N(C)c1cn([PbH])nc1N(C)P</smiles><smiles></smiles>

Amino Carbene (AC) R: $t \mathrm{Bu}, \boldsymbol{A} \boldsymbol{C}^{\mathrm{tBu}}$ $\mathrm{Cy}, \boldsymbol{A C ^ { C y }}$ Mes $\boldsymbol{A} \boldsymbol{C}^{\text {Mes }}$ Imidazolium Aminide (IA) $\mathrm{R}: \mathrm{tBu}, I^{\mathrm{tBu}}$ $\mathrm{Cy}, \mathrm{IA}^{\mathrm{Cy}}$ Mes $I A^{\text {Mes }}$

Scheme 1.

Whereas efforts are directed towards the use of well-defined earth-abundant $\mathrm{NHC}$ metal complexes in homogeneous catalysis, competent $\mathrm{Fe}$ and Co complexes are often generated in-situ, unexpected transformations being possibly overlooked. ${ }^{[8]}$ Herein, we describe fully characterized complexes obtained in the course of a study on metallotropism in $I \boldsymbol{A}$ and $\boldsymbol{A C}$ associated with $\left[\mathrm{M}\left\{\mathrm{N}\left(\mathrm{SiMe}_{3}\right)_{2}\right\}_{2}\right]_{2}(\mathrm{M}=\mathrm{Co}, \mathrm{Fe})$ as a function of $\mathrm{R}$ in $r\left(\mathrm{~N}_{\text {exo }} \mathrm{R}\right)$ and $r\left(\mathrm{Nexo}_{\mathrm{HR}}\right)$. Two types of unexpected and unprecedented products were obtained from thermolysis of the system $I A^{R} \rightleftharpoons A C^{R}(R=t \mathrm{Bu}$, Mes) and $\left[\mathrm{M}\left\{\mathrm{N}\left(\mathrm{SiMe}_{3}\right)_{2}\right\}_{2}\right]_{2}$, the different nature of which can be traced to metallotropism. All the reactions and manipulations were carried out under inert atmosphere (glove-box, $\mathrm{N}_{2}$-sealed ampoules) and all described complexes are (very) sensitive in solution and solid-state to air/moisture (see $\mathrm{SI}$ ).

The equilibrium mixture $I A^{t B u} \rightleftharpoons A C^{t B u}\left(K_{e q}\right.$ at $\mathrm{rt}$ ca. 0.5) reacted with 0.5 equiv. $\left[\mathrm{M}\left\{\mathrm{N}\left(\mathrm{SiMe}_{3}\right)_{2}\right\}_{2}\right]_{2}(\mathrm{M}=\mathrm{Co}, \mathrm{Fe})$ in toluene to give selectively $\mathbf{1 a}$ and $\mathbf{1 b}$ as green and orange crystals, respectively (Scheme 2). Despite their paramagnetism, $\mathbf{1 a}$ and $\mathbf{1 b}$ exhibit diagnostic ${ }^{1} \mathrm{H}-\mathrm{NMR}$ spectra in the region $\delta 100$ to $-50 \mathrm{ppm}$ 
(see SI); no other paramagnetic product could be detected in solution by NMR spectroscopy. The molecular structure of $\mathbf{1 b}$ (Figure 1) reveals trigonal planar geometry with $\mathrm{C}_{\mathrm{NHC}}$-coordinated $\boldsymbol{A} \boldsymbol{C}^{\mathbf{B} u}$ and two bis(trimethylsilyl)amide ligands; the metrical data are very similar to the archetypical $\left[\mathrm{Fe}(\mathrm{IPr})\left\{\mathrm{N}\left(\mathrm{SiMe}_{3}\right)_{2}\right\}_{2}\right]$ with identical sterics (cf. Fe-C $\mathrm{NHC}_{\mathrm{NC}}=2.182(2)$ - 2.184(2) $\AA$ vs. 2.192(3) in $1 \mathrm{~b}$ ); the $\mathrm{NHC}$ plane makes an angle of ca. $42^{\circ}$ with the metal coordination plane. ${ }^{[9]}$ The data set from the weakly diffracting crystals of $\mathbf{1 a}$ established identical atom connectivity to $\mathbf{1 b}$ (Figure S2.3). Interestingly, preliminary reactions of $I A^{t B u} \rightleftharpoons A C^{t B u}$ with the sterically exposed anhydrous $\mathrm{CoCl}_{2}$ led to the $\mathrm{C}_{\mathrm{NHC}}$-metallated halide-bridged complex $\left[\mathrm{Co}\left(\boldsymbol{A} \boldsymbol{C}^{t B u}\right) \mathrm{Cl}(\mu-\mathrm{Cl})\right]_{2}$ (Figure S2.5), further underlining the preferred coordination site of the $A C^{t B u}$ tautomer. Insight into the apparent metal carbophilicity when $\mathrm{R}=t \mathrm{Bu}$ resulted from computational studies (see below).

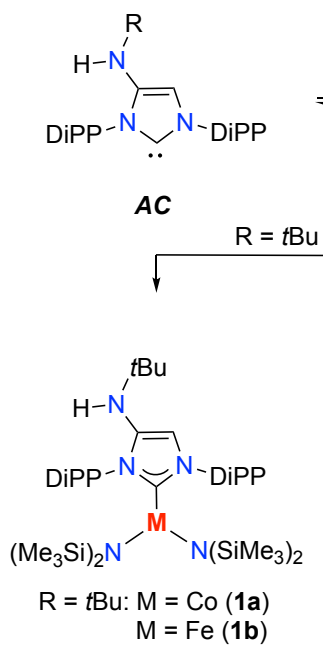

Scheme 2. light yellow paramagnetic solids (Figures 2 and S2.7, respectively). The metals in $\mathbf{2} \mathbf{a} / \mathbf{2} \mathbf{b}$ are in a trigonal planar environment, with a $\mathrm{N}_{\text {exo-coordinated }} \boldsymbol{I} \boldsymbol{A}^{\boldsymbol{c}}$. In $\mathbf{2 a}$ there are two types of Co-N bonds, Co-Nexo (1.993(2) $\AA$ ) being longer than $\mathrm{Co}$ $\mathrm{N}_{\mathrm{N}(\text { SiMe3)2 }}(1.943(2)$ and 1.956(2) $\AA$ ). A analogous metrical trend was found in $\left[\mathrm{Co}\left\{\mathrm{N}\left(\mathrm{SiMe}_{3}\right)_{2}\right\}_{2}\right.$ (pyridine)], with $\mathrm{Co}-\mathrm{N}_{\text {pyridine }}$ and $\mathrm{Co}$ $\mathrm{N}_{\mathrm{N}(\text { SiMe3)2 }}$ at 2.055(5) $\AA, 1.904(3) \AA$, respectively; ${ }^{[10]}$ this comparison places the Co- $\mathrm{N}_{\text {exo }}$ bond distances in the region of Co-Nimine bonds. The conjugated mesomeric betaine $I A^{C_{y}}$ can be classified as an imidazolin-4-imine and expands the class of regioisomeric imidazolin-2-imines recently described. ${ }^{[11]}$ Similar considerations apply to the structure of $\mathbf{2} \mathbf{b}$.

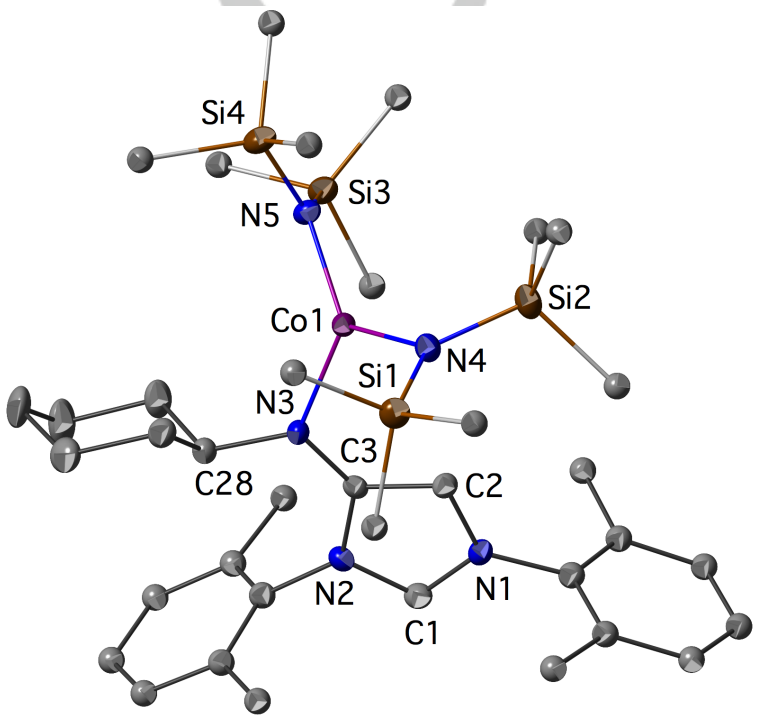

Figure 2. Molecular structure of $\mathbf{2 a}$ (metrical data in $\mathrm{SI}$ ).

DFT calculations have been performed at the (U)M06-2X level for $\boldsymbol{A} \boldsymbol{C}^{R}$ and $\boldsymbol{I} \boldsymbol{A}^{R}$ tautomers and their metal complexes for $\mathrm{R}$ $=t \mathrm{Bu}, \mathrm{Cy}$ and Mes. The case $\mathrm{R}=\mathrm{H}$ has been also studied to serve as a reference (see the $\mathrm{SI}$ for the computational methods and detailed discussion). Each tautomer $I A^{R}$ and $A C^{R}$ can exist in two isomeric forms, with the $R$ substituent at the $N_{\text {exo }}$ site being proximal or distal to the neighboring DiPP. Owing to the steric hindrance of the latter, distal isomers are more stable than proximal ones for $\mathrm{R} \neq \mathrm{H}$, in particular for $\mathrm{R}=t \mathrm{Bu}$. Similarly, the presence of the DiPP substituent renders the coordination of a large metal fragment such as $\mathrm{M}\left[\mathrm{N}\left(\mathrm{SiMe}_{3}\right)_{2}\right]_{2}$ to the $\mathrm{N}_{\text {exo }}$ atom of $I A^{R_{\text {distal }}}$ computationally impossible, in contrast to $\mathrm{N}_{\text {exo }}$ coordination of $I A^{R}$ prox; these results are in agreement with the experimental structures $\mathbf{2 a} / \mathbf{b}$ and $\mathbf{3 b}$. Consequently, coordination of $\mathrm{M}\left[\mathrm{N}\left(\mathrm{SiMe}_{3}\right)_{2}\right]_{2}$ fragments has been further analyzed only for

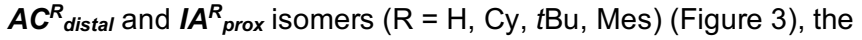
latter ligand being less stable than the former $\left(\mathrm{G}\left(I A^{R}{ }_{\text {prox }}\right)-\right.$ $\mathrm{G}\left(\boldsymbol{A C ^ { R }}{ }_{\text {distal }}\right)=26.2,56.2$ and $10.4 \mathrm{~kJ} \cdot \mathrm{mol}^{-1}$ for $\mathrm{R}=\mathrm{Cy}, \mathrm{tBu}$ and Mes, respectively), except for $\mathrm{R}=\mathrm{H}\left(-2.2 \mathrm{~kJ} \mathrm{~mol}^{-1}\right)$ (Table S4.1).
Figure 1. Molecular structure of 1b; DiPP methyls are omitted (metrical data in $\mathrm{SI})$.

In contrast to the above where $\mathrm{R}=t \mathrm{Bu}$, the reaction of $I \boldsymbol{A}^{C_{y}} \rightleftharpoons \boldsymbol{A} \boldsymbol{C}^{C y}\left(K_{\text {eq }}\right.$ at it ca. 3.2) with $\left[\mathrm{M}\left\{\mathrm{N}\left(\mathrm{SiMe}_{3}\right)_{2}\right\}_{2}\right]_{2}(\mathrm{M}=\mathrm{Co}, \mathrm{Fe})$ led to the isostructural $\mathbf{2} \mathbf{a}$ and $\mathbf{2} \mathbf{b}$ in good yields, as green and 


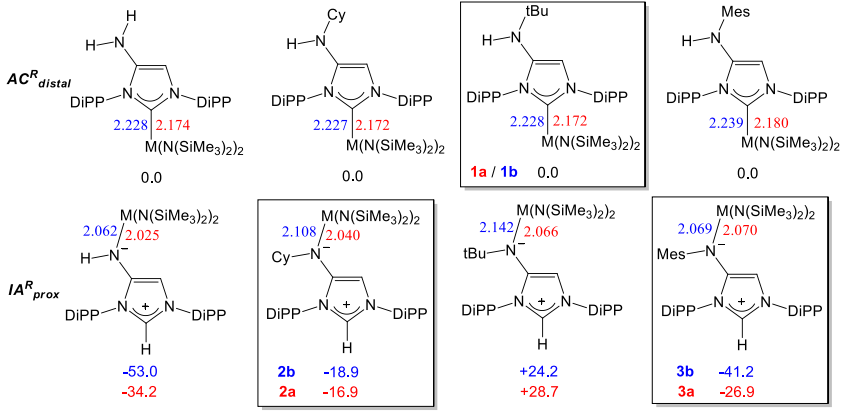

Figure 3. Coordination of $\boldsymbol{A} \boldsymbol{C} \boldsymbol{R}_{\text {distal }}$ and $\boldsymbol{I} \boldsymbol{A} \boldsymbol{R}_{\text {prox }}$ isomers $(\mathrm{R}=\mathrm{H}, \mathrm{Cy}, t \mathrm{Bu}, \mathrm{Mes})$ to $\mathrm{M}\left[\mathrm{N}\left(\mathrm{SiMe}_{3}\right)_{2}\right]_{2}$ fragments. Bond lengths (in $\AA$ ) and relative free energies (in $\mathrm{kJ} \cdot \mathrm{mol}^{-1}$ ) computed at the UM06-2X/def2-TZVPP//UM06-2X/def2-SVP level for $\mathrm{M}=\mathrm{Fe}$ (blue) and Co (red). The structures corresponding to those obtained experimentally have been framed.

The relative free energies of the metal complexes, depending on the $A C^{R}$ distal vs. $I A^{R}$ prox ligand nature, are in excellent agreement with the experimental results: only the most stable complexes have been observed experimentally. Calculations of the Percent Buried Volume $\left(\% V_{b u r}\right)$ of ligands

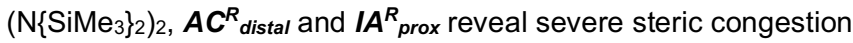
around the metal center and the larger steric demand of ligand $A C^{R}$ distal relative to $I A^{R}$ prox for $\mathrm{R}=\mathrm{Cy}$ and Mes, whereas the opposite is found for $\mathrm{R}=t \mathrm{Bu}$.

Even for $\mathrm{R}=\mathrm{H}$, there is steric hindrance between DiPP and $\mathrm{N}\left(\mathrm{SiMe}_{3}\right)_{2}$ ligands and $\boldsymbol{I}^{\boldsymbol{H}}{ }_{\text {prox }}$ complexes are significantly more stable than $A \boldsymbol{C}^{H_{\text {distal }}}\left(-53.0\right.$ and $-34.2 \mathrm{~kJ} \cdot \mathrm{mol}^{-1}$ for $\mathrm{M}=\mathrm{Fe}$ and $\mathrm{Co}$, respectively). The coordination of the $I A^{R}$ prox ligand to $\left[\mathrm{M}\left\{\mathrm{N}\left(\mathrm{SiMe}_{3}\right)_{2}\right\}_{2}\right]_{2}$ remains preferred to that of $\boldsymbol{A} \boldsymbol{C}^{R}$ distal for $\mathrm{R}=\mathrm{Cy}$ and Mes because the steric repulsion between $\mathrm{R}$ and DiPP groups in $I A^{R_{\text {prox }}}$ induces only a relatively small destabilization and the steric bulk of $I A^{R}$ prox remains smaller than that of $A C^{R}$ distal. In contrast, $I A^{t B u_{p r o x}}$ is strongly destabilized relative to $A C^{t B u}$ distal due to steric hindrance between the DiPP and $t \mathrm{Bu}$ groups. Furthermore, $I A^{t B u_{p r o x}}$ is bulkier than $\boldsymbol{A} C^{t B u_{\text {distal. }} \text {. These combined }}$ steric effects induce the preferred formation of $1 \mathbf{a} / \mathbf{1 b}$ with $A C^{t B u_{\text {distal. }} \text {. }}$.

The mixture $I \boldsymbol{A}^{\text {Mes }} \rightleftharpoons \boldsymbol{A} \boldsymbol{C}^{\text {Mes }}$ reacted with $\left[\mathrm{Fe}\left\{\mathrm{N}\left(\mathrm{SiMe}_{3}\right)_{2}\right\}_{2}\right]_{2}$ only under forcing conditions (toluene, $110^{\circ} \mathrm{C}, 3 \mathrm{~d}$ ) and in the presence of excess $\left[\mathrm{Fe}\left\{\mathrm{N}\left(\mathrm{SiMe}_{3) 2}\right\}_{2}\right]_{2}\right.$ (2:1 on metal basis) giving complex $\mathbf{3 b}$ (isolated in two different isomorphs, Scheme 2, SI and Figures S2.8 and S2.9). In stark contrast, heating of $\boldsymbol{I A}^{\text {Mes }} \rightleftharpoons \boldsymbol{A} \boldsymbol{C}^{\text {Mes }}$ with [Co\{ $\left.\left.\mathrm{N}\left(\mathrm{SiMe}_{3}\right)_{2}\right\}_{2}\right]$ (1:1 ratio on metal basis) at $90{ }^{\circ} \mathrm{C}$ in toluene for ca. $16 \mathrm{~h}$ gave brown crystals of the paramagnetic 4a (Scheme 3 and Figure 4). Plausible reaction steps leading to $4 \mathrm{a}$ are presented in the SI (Scheme S3.3). In contrast, $\left[\mathrm{Fe}\left\{\mathrm{N}\left(\mathrm{SiMe}_{3}\right)_{2}\right\}_{2}\right]$ was unreactive under these conditions and only the starting materials were recovered. The structure of 4a unveiled a unique binuclear mixed-valence complex featuring metalation of the heterocyclic ring ortho to the $\mathrm{N}_{\text {exo }}$ substituent. In 4a, both Co centres (Co1 and Co2 in Figure 5) adopt distorted planar T-shaped geometries (assuming one coordination site along the Co-Co vector). The Co1-Co2 distance (2.5628(3) $\AA$ ) is comparable to that in $\left[\mathrm{Co}_{2}(\mathrm{CO})_{8}\right](2.52 \AA) .{ }^{[12]}$ All Co-N distances (Co1-N3, Co1-N4, Co2-N5) fall into the narrow range characteristic of aminide ligands, with a typical Co- $\mathrm{C}_{\mathrm{NHC}}$ bond distance $(1.951(1) \AA) \cdot{ }^{[13]}$ Thus, a plausible description of the ligand system in $\mathbf{4 a}$ emerging from the metrical data is an aminidefunctionalized mesoionic aNHC, leading to consider $\mathrm{Co}_{1}$ and $\mathrm{Co} 2$ as $\mathrm{Co}^{\prime \prime}$ as $\mathrm{Co}^{\prime}$, respectively. Alternative resonance formulations can be found in the SI (Scheme S3.2). Interestingly, 4a is the only dinuclear complex with two $\operatorname{Co}\left\{\mathrm{N}\left(\mathrm{SiMe}_{3}\right)_{2}\right\}$ moieties and nonbridging $\mathrm{N}\left(\mathrm{SiMe}_{3}\right)_{2}$ groups and represents a rare example of heteroatom-functionalized aNHC.

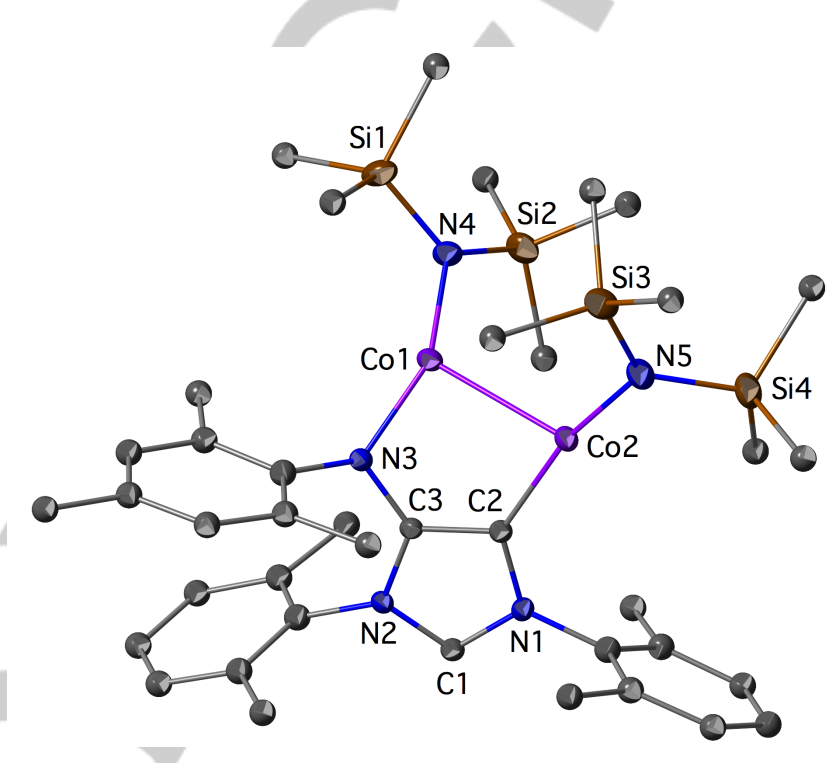

Figure 4. Molecular structure of 4a; DiPP methyls are omitted (metrical data in SI).
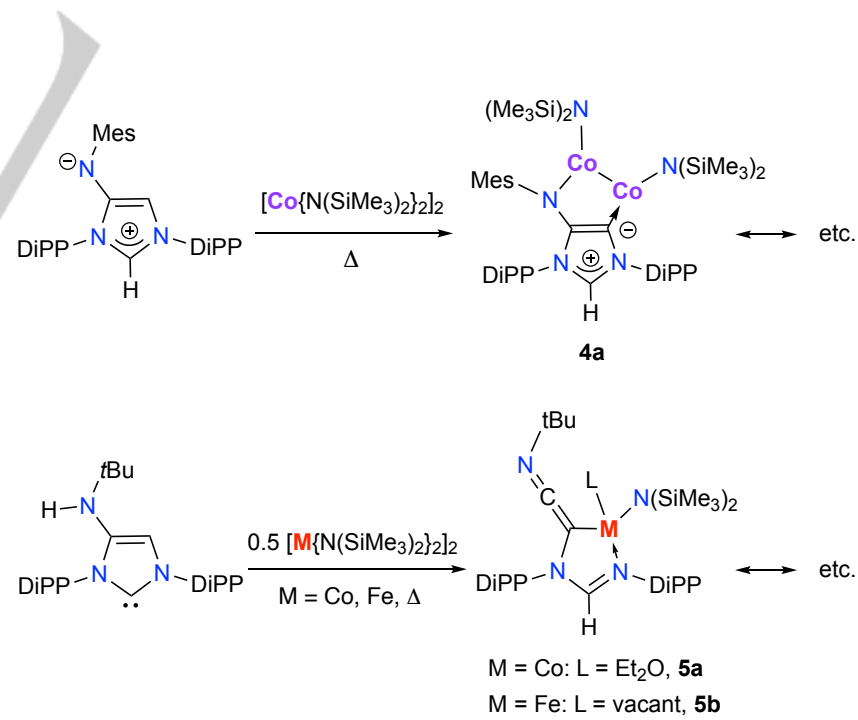

Scheme 3. Thermal rearrangement products of $I A^{\text {Mes }} \rightleftharpoons A C^{\text {Mes }}$ with $\left[\mathrm{Co}\left\{\mathrm{N}\left(\mathrm{SiMe}_{3}\right)_{2}\right\}_{2}\right]_{2}(4 \mathrm{a})$ and of $\boldsymbol{I} \boldsymbol{A}^{\boldsymbol{t B u}} \rightleftharpoons \boldsymbol{A} \boldsymbol{C}^{\boldsymbol{t} \boldsymbol{B} u}$ with $\left.\left[\mathrm{M}\left\{\mathrm{N}\left(\mathrm{SiMe}_{3}\right)_{2}\right\}_{2}\right]_{2}\right](\mathrm{M}=\mathrm{Co}(5 \mathrm{a})$ $\mathrm{Fe}(\mathbf{5 b})$; description by alternative resonance forms is given in the $\mathrm{SI}$.

In contrast to $\mathbf{1 a} / \mathbf{1 b}$, complexes $\mathbf{5 a}$ and $\mathbf{5 b}$ were obtained from the reaction of the tautomeric mixture $I A^{t B u} \rightleftharpoons A C^{t B u}$ with 
$\left[\mathrm{M}\left\{\mathrm{N}\left(\mathrm{SiMe}_{3}\right)_{2}\right\}_{2}\right]_{2}(\mathrm{M}=\mathrm{Co}, \mathrm{Fe})$ in toluene at room temperature for $3 \mathrm{~d}$ or heating at $90^{\circ} \mathrm{C}$ for $1 \mathrm{~h}$ (Scheme 3 and Figures 5 and 6). They were isolated in good yields as purple and red solids that were crystallized from ether or pentane, respectively.

The crystal structures of $\mathbf{5 a}$ and $\mathbf{5 b}$ established the atom connectivity of a ring-opened, rearranged ligand system, and the metrical data proved crucial in extracting the bond orders between the constituent atoms.

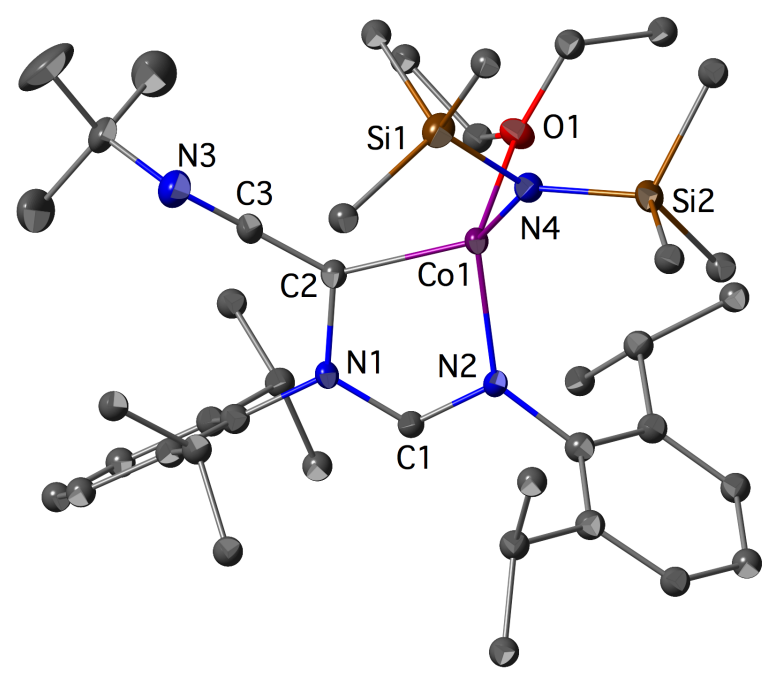

Figure 5. Molecular structure of complex 5a (metrical data in $\mathrm{SI}$ ).

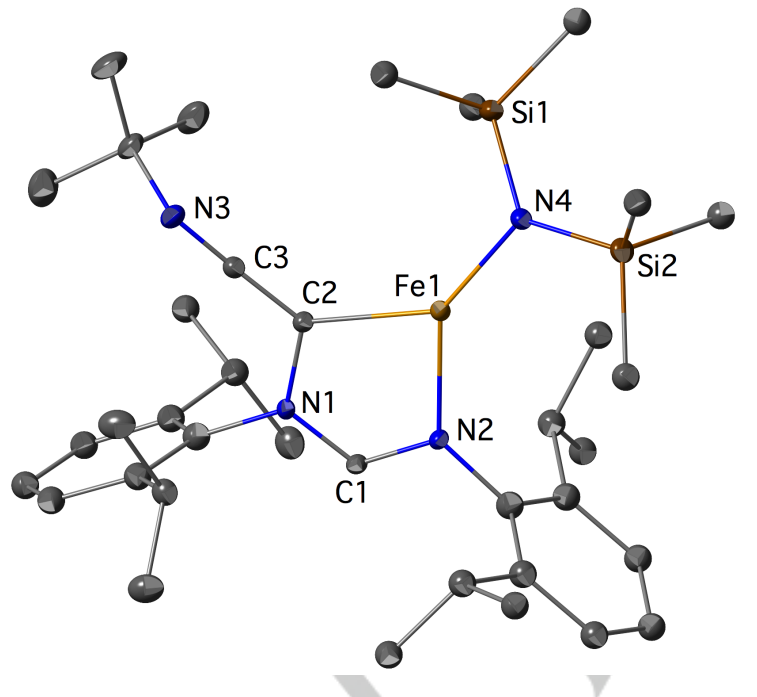

Figure 6. Molecular structure of complex $\mathbf{5 b}$ (metrical data in $\mathrm{SI}$ ).

Although the metals in $\mathbf{5 a}$ and $\mathbf{5 b}$ adopt pseudo-tetrahedral and trigonal planar coordination geometries, respectively, due to coordination of an ether molecule in $\mathbf{5 a}$, the skeleton of the ligand and the associated $\kappa \mathrm{N}, \kappa \mathrm{C}$-coordination are identical in both cases. The metrical data (see SI) support the depicted resonance forms showing the metallated ketenimine structures (Schemes 3 and
S3.3). When complexes $\mathbf{1 a}$ and $\mathbf{1 b}$ were heated in $\mathrm{C}_{6} \mathrm{D}_{6}$ at $90{ }^{\circ} \mathrm{C}$ for $1 \mathrm{~h}$, they fully converted to $\mathbf{5 a}$ and $\mathbf{5 b}$, respectively, which strongly indicates their intermediacy in the formation of the latter, although possible lability of the $\mathrm{M}\left\{\mathrm{N}\left(\mathrm{SiMe}_{3}\right)_{2}\right\}_{2}$ fragment in $\mathbf{1 a} / \mathbf{1 b}$, may point to an alternative rearrangement mechanism (SI).

Skeletal rearrangements of coordinated imidazol(in)-2ylidenes are rare but not unprecedented. Heterocycle ring opening reactions may be preceded by migratory insertion of alkyl co-ligands to the $\mathrm{C}_{\mathrm{NHC}}(\mathrm{Ni}),{ }^{[14]}(\mathrm{Hf}),{ }^{[15]}$ or not:; ${ }^{[16]}$ imidazol(in)-2ylidene ring expansion to 6-membered metallacycles can take place via metal insertion into the $\mathrm{C}-\mathrm{N}$ bond $\left(\mathrm{Ni},{ }^{[17]} \mathrm{Ru}\right) \cdot{ }^{[18]} \mathrm{Ring}$ expansions involving insertion of heteroelements have been described and recently reviewed; ${ }^{[19]}$ remote lithiation preceding SIMes ring opening has recently been reported. ${ }^{[20]}$ Furthermore, hydrolytic cleavage of expanded $\mathrm{NHC}$ coordinated to $\mathrm{Cu}$ has been described. ${ }^{[21]}$ However, the transformation of $\mathbf{1}$ to $\mathbf{5}$ constitutes the first example of $r \mathrm{NHC}$ skeletal rearrangement and the formation of metalla-ketenimines, which may be initiated by remote coordination of the $r \mathrm{NHCs}$ species.

In conclusion, we have demonstrated experimentally and theoretically that the tautomers involved in the equilibrium $I A^{R} \rightleftharpoons A C^{R}$ adopt diverse coordination modes with the fragment $\mathrm{M}\left[\left\{\mathrm{N}\left(\mathrm{SiMe}_{3}\right)_{2}\right\}_{2}\right](\mathrm{M}=\mathrm{Co}, \mathrm{Fe})$, depending on the nature of the $\mathrm{R}$ substituent of the $\mathrm{N}_{\text {exo }}$ atom. The preference towards $k \mathrm{C}$ or $k \mathrm{~N}$ coordination as a function of $\mathrm{R}$ correlates with the nature of the most abundant tautomer in the $I A^{R} \rightleftharpoons A C^{R}$ equilibrium. Owing to the bulk of the metal fragment, its coordination to the $I A^{R}$ forms (R = Cy, Mes) is accompanied by reorientation of the $N_{\text {exo }} R$ group from dist to prox; in the $A C^{t B u}$ case, reorientation is irrelevant, since the metal fragment is coordinated to the $\mathrm{C}_{\mathrm{NHC}}$. However, the reactivity of the $I \boldsymbol{A}^{\boldsymbol{t B u}} \rightleftharpoons \boldsymbol{A} \boldsymbol{C}^{\boldsymbol{t B u}} /\left[\mathrm{M}\left\{\mathrm{N}\left(\mathrm{SiMe}_{3}\right)_{2}\right\}_{2}\right]_{2}$ system at elevated temperature features ring opening of the heterocyclic ring moiety and rearrangement to metallacycles comprising metallated ketenimines. In contrast, with $I A^{\text {Mes }} \rightleftharpoons A C^{\text {Mes }}$, formation of a dinuclear mixed valence complex with functionalized aNHC occurred for $\mathrm{M}=\mathrm{Co}$ only. Based on the computed stability of the $r(\mathrm{NHC})$ metal silylamide adducts, it may be plausible to associate the divergent rearrangement patterns with the metallotropism, i.e. coordination of the $\mathrm{C}_{\mathrm{NHC}}$ or $\mathrm{N}_{\text {exo }}$ sites. This contention is based on coordination modes established by $\mathrm{X}$-ray diffraction on welldefined complexes, but in-situ mechanistic investigations were hampered by paramagnetism. Predissociation of $\mathrm{M}\left[\mathrm{N}\left(\mathrm{SiMe}_{3}\right)_{2}\right]_{2}$ governed by temperature or electronic and steric effects of the substituent cannot be ruled out. At present, studies of the catalytic chemistry with $r \mathrm{NHC}$ complexes, in particular of $3 \mathrm{~d}$ metals, are very sparse, and the results described herein point to a complex coordination chemistry, which may have considerable repercussions in future catalytic applications.

\section{Acknowledgements}

The USIAS, CNRS, Unistra, Région Alsace and Communauté Urbaine de Strasbourg are acknowledged for the award of fellowships and a Gutenberg Excellence Chair (2010-11) to AAD. We also thank the International Centre for Frontier Research in Chemistry (FRC Strasbourg) and the CNRS and the MESR (Paris) for funding. We thank Miss Corinne Bailly and Dr Lydia 
Karmazin (Service de Radiocristallographie, Unistra) for the determination of the crystal structures.

\section{Conflict of interest}

The authors declare no conflict of interest.

Keywords: cobalt $\bullet$ dinuclear complex $\cdot \mathrm{N}$-heterocyclic carbenes - iron • metallotropism

[1] a) J. I. Bates, P. Kennepohl, D. P. Gates, Angew. Chem. Int. Ed. 2009, 48, 9844-9847; b) D. Mendoza-Espinosa, B. Donnadieu, G. Bertrand, J. Am. Chem. Soc. 2010, 132, 7264-7265; c) P. K. Majhi, G. Schnakenburg Z. Kelemen, L. Nyulaszi, D. P. Gates, R. Streubel, Angew. Chem. Int. Ed. 2013, 52, 10080-10083; d) P. K. Majhi, K. C. F. Chow, T. H. H. Hsieh, E. G. Bowes, G. Schnakenburg, P. Kennepohl, R. Streubel, D. P. Gates, Chem. Commun. 2016, 52, 998-1001; e) V. César, J.-C. Tourneux, N. Vujkovic, R. Brousses, N. Lugan, G. Lavigne, Chem. Commun. 2012, 48, 2349-2351; f) A. A. Danopoulos, K. Yu. Monakhov, P. Braunstein, Chem. Eur. J. 2013, 19, 450-455; g) A. A. Danopoulos, P. Braunstein, E. Rezabal, G. Frison, Chem. Commun. 2015, 51, 3049-3052; h) V. Karthik, I. A. Bhat, G. Anantharaman, Organometallics 2013, 32, 7006-7013; i) J. P. Moerdyk, C. W. Bielawski, Chem. Commun. 2014, 50, 4551-4553.

[2] a) K. Schwedtmann, R. Schoemaker, F. Hennersdorf, A. Bauza, A Frontera, R. Weiss, J. J. Weigand, Dalton Trans. 2016, 45, 11384-11396; b) M. Ruamps, N. Lugan, V. César, Organometallics 2017, 36, 10491055.

[3] a) A. Nasr, A. Winkler, M. Tamm, Coord. Chem. Rev. 2016, 316, 68-124; b) H. Schneider, D. Schmidt, U. Radius, Chem. Eur. J. 2015, 21, 27932797.

[4] a) J. Ruiz, A. F. Mesa, Chem. Eur. J. 2012, 18, 4485-4488; b) Z. Han, J. I. Bates, D. Strehl, B. O. Patrick, D. P. Gates, Inorg. Chem. 2016, 55, 5071-5078.

[5] a) C. Farber, M. Leibold, C. Bruhn, M. Maurer, U. Siemeling, Chem. Commun. 2012, 48, 227-229; b) C. Thie, S. Hitzel, L. Wallbaum, C. Bruhn, U. Siemeling, J. Organomet. Chem. 2016, 821, 112-121.

[6] A. Schmidt, S. Wiechmann, T. Freese, ARKIVOC 2013, 424-469.

[7] A. A. Danopoulos, P. Braunstein, Chem. Commun. 2014, 50, 3055-3057.

[8] a) K. Riener, S. Haslinger, A. Raba, M. P. Högerl, M. Cokoja, W. A. Herrmann, F. E. Kühn, Chem. Rev. 2014, 114, 5215-5272; b) I. Bauer H.-J. Knölker, Chem. Rev. 2015, 115, 3170-3387; c) Q. Liu, L. Wu, R. Jackstell, M. Beller, Nature Comm. 2015, 6, 5933; d) S. Hameury, P. de
Frémont, P. Braunstein, Chem. Soc. Rev., 2017, 46, 632-733; d) V. Charra, P. de Frémont, P. Braunstein, Coord. Chem. Rev. 2017, 341, 53176; e) J. Loup, D. Zell, J. C. A. Oliveira, H. Keil, D.Stalke, L. Ackermann, Angew. Chem. Int. Ed. 2017, 56, 14197-14201, Angew. Chem. 2017, 129, 14385-14389.

[9] R. A. Layfield, J. J. W. McDouall, M. Scheer, C. Schwarzmaier, F. Tuna Chem. Commun. 2011, 47, 10623-10625.

[10] C. Y. Lin, J. C. Fettinger, N. F. Chilton, A. Formanuik, F. Grandjean, G. J. Long, P. P. Power, Chem. Commun. 2015, 51, 13275-13278.

[11] X. Wu, M. Tamm, Coord. Chem. Rev. 2014, 260, 116-138.

[12] G. G. Sumner, H. P. Klug, L. E. Alexander, Acta Crystallographica 1964, 17, 732-742.

[13] A. Massard, P. Braunstein, A. A. Danopoulos, S. Choua, P. Rabu, Organometallics 2015, 34, 2429-2438.

[14] D. Pugh, A. Boyle, A. A. Danopoulos, Dalton Trans. 2008, 1087-1094.

[15] D. Prema, Y. L. N. Mathota Arachchige, R. E. Murray, L. M. Slaughter, Chem. Commun. 2015, 51, 6753-6756.

[16] W. Zuo, P. Braunstein, Dalton Trans. 2012, 41, 636-643.

[17] A. W. Waltman, T. Ritter, R. H. Grubbs, Organometallics 2006, 25, 42384239.

[18] H.-J. Liu, M. S. Ziegler, T. D. Tilley, Polyhedron 2014, 84, 203-208.

[19] S. Wurtemberger-Pietsch, U. Radius, T. B. Marder, Dalton Trans. 2016, 45, 5880-5895.

[20] A. Hernán-Gómez, A. R. Kennedy, E. Hevia, Angew. Chem. Int. Ed. 2017, $56,6632-6635$.

[21] L. R. Collins, I. M. Riddlestone, M. F. Mahon, M. K. Whittlesey, Chem Eur. J. 2015, 21, 14075-14084.

[22] $\operatorname{CCDC} 1854989\left(\boldsymbol{A C}^{\mathbf{t B u}}\right), 1854990\left(\boldsymbol{I A}^{\text {Mes }}\right), 1854987$ (1b), 1854995 (2a), 1854988 (2b), $1854992\left(\left[\mathrm{Co}\left(\boldsymbol{A} \boldsymbol{C}^{\mathbf{t B u}}\right) \mathrm{Cl}(\mu-\mathrm{Cl})\right]_{2} \cdot 2\left(\mathrm{C}_{7} \mathrm{H}_{8}\right)\right), 1854991$ (3b isom. A), 1854993 (3b, isom. B), 1854996 (4a), 1854994 (5a), and 1854986 (5b) contain the supplementary crystallographic data for this paper. These data can be obtained free of charge from The Cambridge Crystallographic Data Centre. 


\section{Entry for the Table of Contents}

\section{COMMUNICATION}

\section{Metallotropism in tautomers} arises from stereoelectronic finetuning of $(\mathrm{Fe}$ or $\mathrm{Co})\left\{\mathrm{N}\left(\mathrm{SiMe}_{3}\right)_{2}\right\}_{2}$ bonding to $\mathrm{C}_{\mathrm{NHC}}$ or remote $\mathrm{N}$ in $\mathrm{NHCs} /$ imidazolium salts with amine/aminide substituents, respectively. Thermally-induced unexpected formation of a $\mathrm{Co}^{\prime}-\mathrm{Co}^{\prime \prime}$ dinuclear complex and $\mathrm{NHC}$ ring opening leading to

metallaketenimines were observed.

$$
\text { DiPP- }
$$

$\left(\mathrm{Me}_{3} \mathrm{Si}\right)_{2} \mathrm{~N}$ $\left(\mathrm{Me}_{3} \mathrm{Si}_{2}\right)^{-\mathrm{N}^{-}}-\mathrm{N}\left(\mathrm{SiMe}_{3}\right)_{2}$ Cy-N $\operatorname{DiPP}-\mathrm{N}_{\mathrm{H}}^{ \pm} \mathrm{N}-$ DiPP $\mathrm{M}=\mathrm{Co}, \mathrm{Fe}$

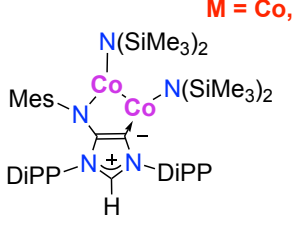

Andreas A. Danopoulos, * Alexandre Massard, Gilles Frison, and Pierre Braunstein*

Page No. - Page No.

Iron and Cobalt Metallotropism in Remote-Substituted NHC Ligands, Metallation to Abnormal NHC Complexes or NHC Ring Opening 